\title{
EDUTECH
}

\section{PENERAPAN METODE VASTMIND PADA MAHASISWA BIMBINGAN TINGKAT AKHIR UNTUK MONITORING PERSENTASE CAPAIAN PENYELESAIAN PROYEK PENELITIAN}

\section{Oleh :}

Diah Aryani, Dian Mustika Putri,Untung Rahardja, Qurotul Aini,

\section{STMIK Raharja}

Jl. Jendral Sudirman No. 40, Modernland Cikokol, Tangerang 15117

Email: diah.aryani@raharja.info,mustika@raharja.info,untung@raharja.info, aini@raharja.info

Abstrak. In today's disruptive era, in addition to the technology that keeps developing and innovating, educational instruments are also required to have thinking skills as agent of change. Learning methods develop following the dynamic mindset from all perspectives and students are the main research object in the success of learning method application. Unfortunately, there has not been a suitable learning method to be used during the advising process so that the entire progress of the project under study cannot be effectively supervised. After the implementation of vasTmind as the collaborative learning method, the project was resolved structurally, systematically, and effectively with the help of mindomo tool that can be accessed online by the students. VasTmind instruments include center (research title), branch in the form of a work list equipped with serial ID number, project objectives, and contributors. VasTmind application offers four benefits including systematic neat thinking, collaborative learning, project mapping, and gamification efficiency. The research found that collaborative learning using vasTmind improved the efficiency and effectiveness of students' project completion outcomes.
Informasi Artikel :

Artikel diterima 13 Januari 2019

Perbaikan 25 Januari 2019

Diterbitkan 14 Februari 2019

Terbit Online 15 Febuari 2019

Kata kunci: Mindomo, vasTmind, Collaborative Learning, Gamifikasi

\section{A. PENDAHULUAN}

Menurut Puspita (2018), para penyelenggara pendidikan sudah barang tentu memahami dengan baik, bahwa perkembangan pendidikan bukan hanya ditentukan dari sisi fasilitas, sarana dan prasarana melainkan dilihat dari sumber daya manusia yang dimiliki. Setiap perguruan tinggi membutuhkan kompetensi serta kapabilitas sebagai upaya perbaikan dan pengembangan yang menjadi keunggulannya, agar dapat menunjukkan kualitas dan eksistensinya dan mampu bersaing No. SK Akreditasi Ristekdikti : 34/E/KPT/2018 dengan perguruan tinggi yang lain. Menurut Untung Rahardja dkk (2017), perguruan tinggi sebagai tempat menjalankan pendidikan, harus memperhatikan dan memahami dengan baik 10 (sepuluh) standar pendidikan nasional, salah satunya adalah standarisasi proses pembelajaran. Dimana, paradigma pendidikan dari masing-masing perguruan tinggi harus memiliki implikasi yang besar dalam menghasilkan sumber daya manusia (SDM) yang berkualitas.

Menurut Atmadja (2018), langkah 
awal dalam peningkatan kualitas pendidikan pada perguruan tinggi adalah dimulai dengan adanya peningkatan mutu dosen, karena dosen merupakan kunci operasional utama proses pendidikan di perguruan tinggi, hal ini otomatis berimplikasi pada proses pencapaian kinerja mahasiswa. Menurut Untung Rahardja dkk (2016), setiap dosen tentu memiliki kelebihan dan kekurangan melalui metode pembelajaran yang diterapkan, namun yang akan mencapai hasil maksimal adalah metode pembelajaran efektif yang mudah diterima oleh mahasiswa dan memberikan kemudahan dalam meningkatkan kualitas pembelajaran.

Menurut Sudaryono dkk (2017), bergeraknya teknologi ke arah yang semakin maju ini, perguruan tinggi didorong untuk menghasilkan inovasi baru dalam sistem pembelajaran pada pelaksanaan kegiatan akademik, dimana sistem pembelajaran ini bersifat praktis dan efektif, mudah diakses kapanpun dan dimanapun. Kolaborasi antara perkembangan teknologi dengan metode pembelajaran yang diterapkan menghasilkan efektivitas pembelajaran, sebuah pembelajaran yang menggunakan media teknologi dapat meningkatkan motivasi, nilai, dan sikap dari para siswa terhadap pembelajaran, serta evaluasi pengalaman belajar mereka. Namun menurut Qurotul Aini dkk
(2018), adanya sebuah inovasi tersebut juga perlu diseimbangkan dengan kemampuannya dalam penyampaian informasi yang diberikan, hingga dapat diterima oleh para pengguna.

Menurut Shapiro dkk (2017), dari berbagai metode pembelajaran yang diterapkan kepada mahasiswa, faktor pendukung keberhasilan suatu pembelajaran adalah dengan adanya motivasi yang dimiliki oleh masing-masing mahasiswa. Motivasi memiliki peran utama dan berandil besar dalam peningkatan kualitas pembelajaran pada lingkungan pendidikan, dan juga peningkatan terhadap persentase keterlibatan mahasiswa dalam berbagai hal konteks pembelajaran.

Pada studi kasus mahasiswa bimbingan tugas akhir atau skripsi di Perguruan Tinggi Raharja saat ini, memegang peranan masing-masing dalam menuntaskan project penelitian, yang dituntut dapat memberikan implikasi berupa kualitas dan kuantitas kinerja yang signifikan. Dalam upaya menyelesaikan project bersifat besar yang belum tentu dapat diselesaikan satu sampai dua hari melainkan bermingguminggu, tentunya membutuhkan media pembelajaran yang disertai keterampilan untuk pada akhirnya dapat menguasai dan menyelesaikan pekerjaan itu secara sistematis. Project yang dikerjakan bukan 
bersifat individu melainkan teamwork, dibutuhkan media collaborative learning, untuk memudahkan tim dapat menyelesaikan list pekerjaan. Dengan rumus $5 \mathrm{~W}+1 \mathrm{H}$, yang harus diperhatikan yaitu kapan harus mulai dan selesai tepat waktu (when), siapa saja yang ikut berkontribusi dalam penelitian (who), daftar pekerjaan apa saja yang harus diselesaikan (what), kenapa pekerjaan ini butuh diselesaikan (why), tempat dan peralatan yang dibutuhkan untuk penyelesaian project (where), dan bagaimana caranya untuk dapat menyelesaikan dengan baik (how).

Namun faktanya, banyak project belum dapat terselesaikan dengan baik, padahal tersedia alat pendukung seperti project management tools, mind-map, flowchart, use case diagram, dan lainlain. Dengan adanya permasalahan tersebut, muncul pemikiran bahwa tidak ada masalah dengan alat pendukung pembelajaran yang tersedia (hardware and software) melainkan lebih ke arah teknik keterampilan dalam mengatur, mengelola, serta menggunakannya (brainware). Sehingga, dibutuhkan mekanisme pemikiran, dimana menggunakan alat apapun, mahasiswa dapat menyelesaikan project yang menjadi tanggung jawab mereka. Dikolaborasikan lah project mahasiswa tersebut dengan menggunakan pemetaan pikiran. Menurut Latifah dkk (2017), peta pikiran (mind mapping) akan mampu meningkatkan kemampuan berpikir kritis mahasiswa, karena dibuat dan dibabgun sendiri berdasarkan alur pemikiran mahasiswa. Dalam hal ini, mahasiswa membutuhkan sebuah metode jitu untuk dapat digunakan dalam menyelesaikan pekerjaan-pekerjaan atau project tersebut. Metode ini disebut vasTmind.

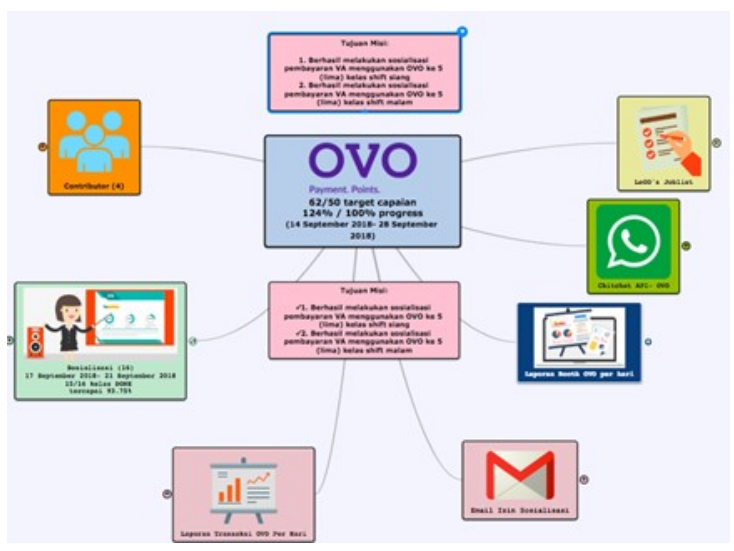

Gambar 1. VasTmind Project

Apa itu vasTmind? VasTmind merupakan metode pembelajaran visualisasi berbasis mindmapping, penyelesaian pekerjaan atau project dengan sistematis, efektif dan efisien berupa mindmapping dengan mengimplementasikan mindomo. Vas singkatan dari kanvas yang artinya mengilustrasikan sebuah project dimulai. Vast adalah istilah dalam bahasa Inggris, yang artinya sangat luas tiada ujungnya, hal ini menyatakan bahwa vasTmind menjadi tempat luas yang membentang 
untuk penyelesaian pekerjaan yang bervariasi. St diartikan steps, dimana segmentasi pekerjaan dilakukan terurai dalam berbagai versi sehingga pekerjaan menjadi terlihat simple and manageable. Mind adalah simbolis dari otak kita, merupakan suatu daya pikir dan kreativitas yang tidak terhingga bagai alam semesta.

Berdasarkan uraian di atas, dapat dikatakan bahwa vasTmind bukan hanya sekedar mindmapping namun juga menjadi virtualisasi dari otak kita, menjadi media pembelajaran kolaboratif, serta bersifat informatif untuk melihat perkembangan project yang sedang berjalan, atau yang sudah terselesaikan.

Penelitian ini dilakukan penulis dengan menggunakan metode case study pada 1 (satu) kelompok mahasiswa bimbingan tugas akhir yang sedang menjalankan penelitian proyek skripsi pada Perguruan Tinggi Raharja. Melewati 5 (lima) alur penelitian sebagai berikut:

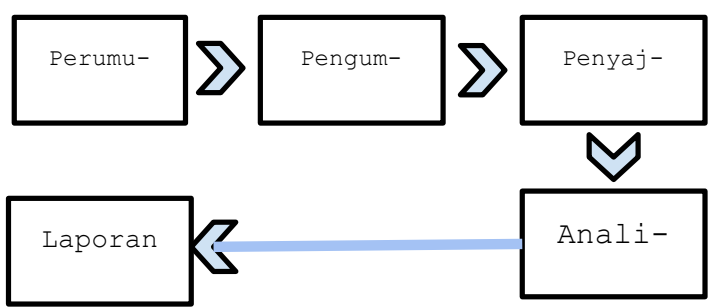

Gambar 2. Metode Penelitian

1. Perumusan masalah: terdapat 3 (tiga) rumusan masalah yang perlu dianali- sa dan dicari penyelesaiannya: 1) Bagaimana cara kerja penerapan metode vasTmind yang baik dalam proses bimbingan?; 2) Bagaimana vasTmind dapat meningkatkan persentase penyelesaian penelitian mahasiswa?; 3) Apa saja bagian-bagian pada vasTmind yang perlu digunakan Mahasiswa, untuk mengukur perbandingan penyelesaian projek?

2. Pengumpulan data: Pengumpulan data menggunakan metode observasi partisipatif, dimana penulis ketiga ikut ambil bagian menjadi sampel 1 (satu) kelompok mahasiswa bimbingan tingkat akhir Perguruan Tinggi Raharja yang terdiri dari 8 (delapan) orang mahasiswa, yang sedang menjalankan projek penelitian sejenis selama periode bimbingan tingkat akhir atau skripsi.

3. Penyajian data: Data yang tersaji dalam bentuk screenshoot penerapan vasTmind dalam proses bimbingan mahasiswa, kemudian dijelaskan secara kualitatif dan kuantitatif.

4. Analisa Data: Data yang terkumpul kemudian dilakukan analisa guna memecahkan rumusan masalah yang dibuat.

Selain menggunakan 5 (lima) alur penelitian studi kasus tersebut, penulis 
menggunakan 5 (lima) studi literature review sebagai sumber penelitian ini. Menurut Dian Mustika Putri dkk (2019), Literature review digunakan untuk menyempurnakan penelitian-penelitian yang sebelumnya untuk mendapatkan landasan teori yang kuat, sebagai berikut:

1. Penelitian yang dilakukan oleh Ananda Karunarathne dan W.A.M.K. Weerasinghe dengan judul "The application of mind mapping as a technique to enhance collaborative, creative, and innovative learning among Geography undergraduates" pada tahun 2014. Penelitian ini membahas mengenai hasil pemetaan pikiran dari sekelompok siswa mengenai topik yang sama, namun peta pikiran yang dihasilkan berbeda dengan berbagai dimensi. Hal ini menghasilkan mahasiswa yang lebih kreatif, inovatif dan kolaboratif dalam belajar.

2. Penelitian yang dilakukan oleh Martin Davies dengan judul "Concept mapping, mind mapping and argument mapping: what are the differences and do they matter?" pada tahun 2011. Penelitian ini memaparkan 3 (tiga) jenis pemetaan pemikiran yaitu concept mapping, mind mapping dan argument mapping. Perbedaan alat yang digunakan tergantung pada tujuan yang hendak dicapai pa- ra peneliti yang pastinya memiliki tujuan yang berbeda-beda, dengan 3 (tiga) jenis pemetaan tersebut, diharapkan dapat saling melengkapi.

3. Penelitian yang dilakukan oleh Joeran Beel, Stefan Langer, Georgia Kapitsaki dengan judul "Exploring the Potential of User Modeling Based on Mind Maps" pada tahun 2015. Penelitian ini menjelaskan tentang perbandingan penggunaan 2 (dua) tools pemetaan pikiran yang efektif berdasarkan rasio klik tayang (RTK) yaitu Mind-Meister and Mindomo. Penelitian ini memaparkan bahwa model peta pikiran yang dibuat oleh pengguna merupakan potensi tinggi dalam menghasilkan pemetaan pikiran yang efektif, dan dapat dijadikan rekomendasi sebagai alat yang tepat dalam melakukan pemetaan pikiran.

4. Penelitian yang dilakukan Dmitrij Koznov dan Michel Pliskin dengan judul "Computer-Supported Collaborative Learning with Mind-Maps" pada tahun 2008. Penelitian ini menjelaskan mengenai metode pembelajaran kolaboratif dengan bantuan teknologi informasi dan komunikasi modern berupa web co-mapping yang menyediakan fasilitas luas dan berbagai cara dalam pengembangan 
peta pikiran serta proses pembelajaran kolaboratif dengan menerapkan Computer-Supported Collaborative Learning (CSCL).

5. Penelitian yang dilakukan J. Michael Spector dan Seung Won Park dengan judul "Motivation, Learning, and Technology: Embodied Educational Motivation" pada tahun 2017. Penelitian ini menjelaskan tentang peranan teknologi sebagai salah satu faktor kognitif yang berhubungan dengan motivasi pendidikan, yaitu aspek yang mempengaruhi intelektual siswa dalam berpikir dan memecahkan masalah. Perkembangan keterampilan intelektual tersebut muncul karena adanya teknologi yang semakin berkembang, khususnya dalam pola pikir manusia. Cara yang jelas adalah melalui peta konsep atau mind-mapping yang menarik. Kegiatan dalam membuat mind-mapping ini adalah kegiatan yang kreatif dalam menuangkan pikiran masing-masing siswa. Hasilnya adalah berupa rasa percaya diri dan mengembangkan diri, yang berimbas berupa bentuk motivasi diri siswa, dan hasil yang diperoleh dari sejauh mana usaha tersebut berhasil. Dari 5 (lima) literature review di atas, dapat disimpulkan bahwa belum adanya metode mind-mapping berbasis collaborative learning yang dapat memberikan pengaruh signifikan terhadap perkembangan project mahasiswa bimbingan. Sehingga, muncullah penelitian mengenai vasTmind yang dapat dijadikan metode collaborative learning, untuk monitoring kualitas kinerja mahasiswa bimbingan.

\section{B. HASIL DAN PEMBAHASAN}

VasTmind merupakan representatif dari mind-mapping, menurut Muhammad Nur dkk (2018), mind-mapping merupakan suatu metode pembelajaran kooperatif, untuk mahasiswa dapat menyampaikan gagasan, catatan, serta merencanakan tugas baru.

Dalam arti global, vasTmind merupakan kumpulan seluruh proses penyelesaian proyek untuk mencapai tujuan yang sama. Untuk menyelesaikan proyek penelitian dengan menerapkan metode collaborative learning pada vasTmind, perlu mengetahui bagian-bagian penting pada vasTmind. Menurut Bambang Anwar dkk (2017), collaborative learning bertujuan untuk meningkatkan kemampuan kognitif mahasiswa untuk saling bekerjasama dalam menyelesaikan permasalahan. Oleh karena itu, terdapat 4 (empat) bagian penting pada vasTmind, yaitu 1.) Centre terdiri dari judul, versi dari project tersebut list pekerjaan, ca- 
paian, persentasi capaian, dan waktu pengerjaan. 2.) Branch adalah cabang dalam pekerjaan ini, yang di dalamnya terdapat list pekerjaan yang memiliki nomor urut pekerjaan, yang semua ada bukti dan hasilnya. 3. Tujuan maksimal 2, adalah hasil akhir yang ingin dicapai oleh tim penelitian. 4. Contributor adalah petugas yang menyelesaikan list pekerjaan ini.

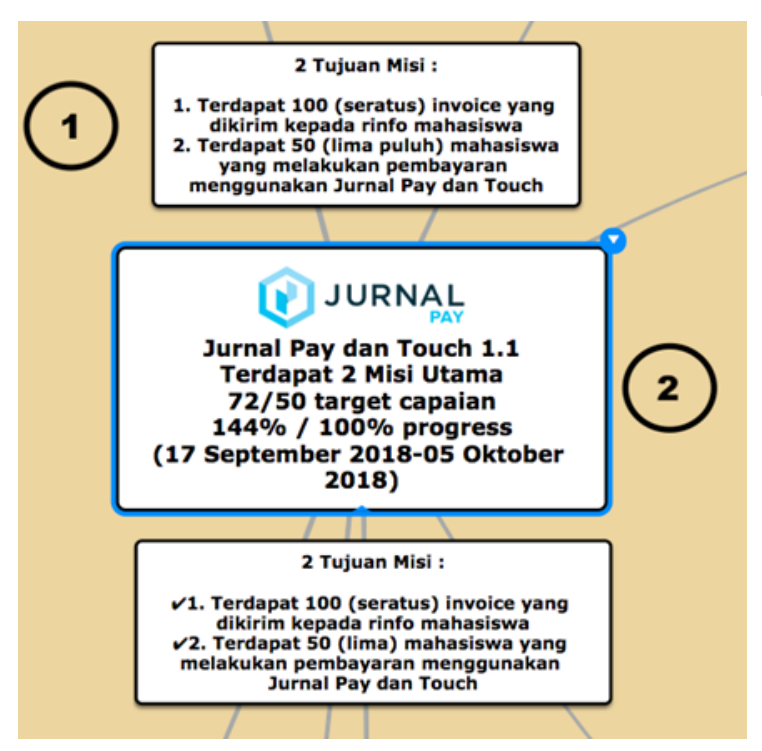

Gambar 2. VasTmind Penelitian kelompok A

Gambar 2 merupakan vasTmind project kelompok A. Nomor 1 merupakan tujuan yang ingin dicapai, dan nomor 2 bagian centre yang merupakan bagian untuk menunjukkan persentase capaian yang sudah dilakukan oleh kelompok penelitian tersebut. Tentunya, angka persentase tersebut bukan hanya sekedar angka, mahasiswa harus menyertakan bukti penyelesaian proyek, berupa link yang dapat diakses oleh dosen pembimbing untuk dijadikan evaluasi dan penilaian.

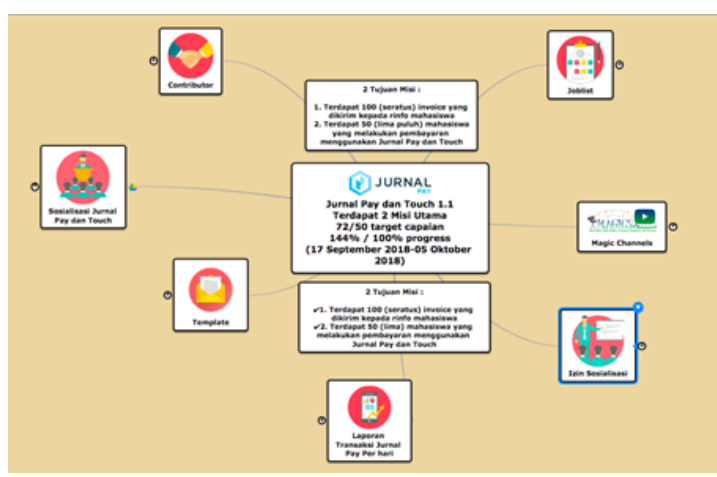

Gambar 3. Tampilan vasTmind Keseluruhan

Pada gambar 3 di atas, dapat dilihat bahwa, terdapat branch yang menghubungkan list pekerjaan proyek yang sudah dijalankan. Apabila diperbesar, maka tampilan untuk joblist seperti gambar di bawah ini

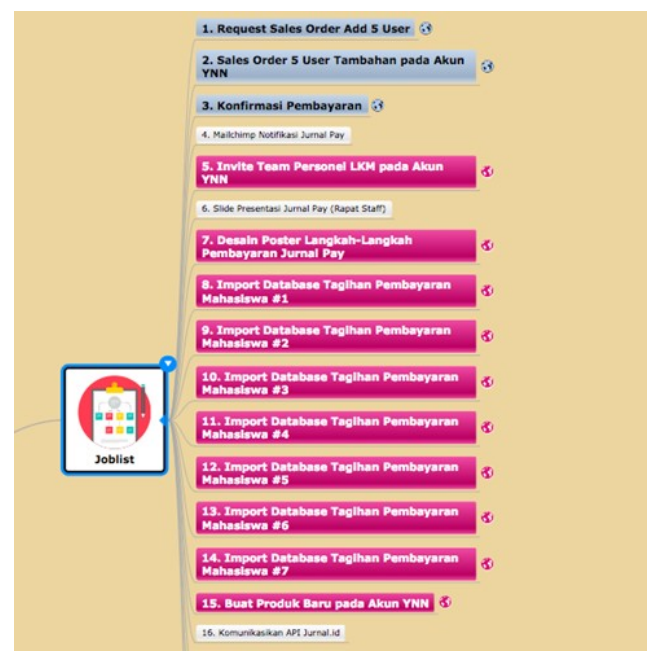

Gambar 4. Joblist Project Mahasiswa 
Pada gambar 4, terlihat daftar pekerjaan yang sudah dikerjakan oleh kelompok, dan disertai dengan bukti yang dapat dilihat dari adanya simbol globe, yang apabila diklik dapat langsung mengarah ke pembuktian proyek. Perbedaan warna mewakili contributor (mahasiswa), dimana pada bagian contributor terlihat daftar mahasiswa yang ikut berkontribusi dalam penyelesaian proyek penelitian, dapat dilihat pada gambar di bawah ini

Pada gambar 5, terlihat 4 (empat) mahasiswa sebagai kontributor yang terlibat dalam penyelesaian proyek, dengan warna yang berbeda. Dapat dilihat juga setiap mahasiswa mewakili angka-angka yang berbeda, hal ini dikarenakan capaian penyelesaian proyek setiap mahasiswa berbeda. Setiap proyek yang sudah dijalankan oleh masing-masing maha-

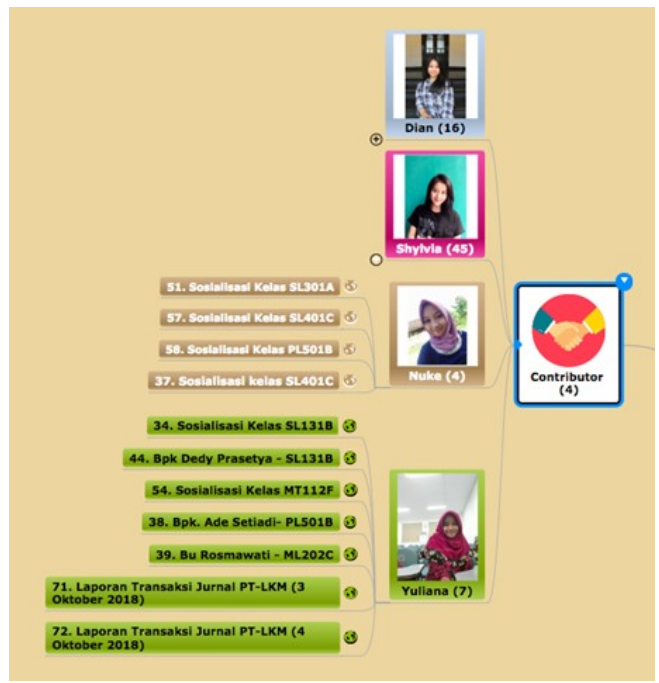

Gambar 5. Kontributor Penelitian siswa terlihat secara jelas, dengan disertai bukti berupa link penyelesaian. Dan hal ini dapat dijadikan salah satu faktor penilaian objektif individu oleh dosen pembimbing untuk mahasiswa bimbingannya.

Terdapat 4 (empat) manfaat dari adanya vasTmind, yaitu:

1.Sistematika pemikiran yang rapih, bukan hanya untuk satu orang tetapi untuk satu tim/kelompok penelitian.

2.Saling mengetahui siapa yang sedang mengerjakan dan bagian apa yang sedang dikerjakan oleh masing-masing mahasiswa, sehingga teratur atau sistematis dan tidak tabrakan, dalam kolaborasi yang harmonis.

3.Pernyataan tegas diantara yang mana yang sudah selesai dan yang mana yang belum diselesaikan. Dan secara keseluruhan terselesaikan atau tidak, sehingga meningkatkan tanggungjawab masing-masing mahasiswa yang terlibat dalam kelompok penelitian tersebut.

4.Gamifikasi yang berjalan diantaranya jelas adanya kontributor yang paling banyak berkontribusi dalam proyek dan yang paling sedikit kontribusinya dalam proyek. Menurut Untung Rahardja dkk (2018) gamifikasi merupakan suatu metode pembelajaran berbasis game yang dipakai guna meningkatkan motivasi mahasiswa dalam belajar, di- 
mana mahasiswa dapat menunjukkan kemampuan terbaiknya diantara rekan satu tim lainnya. Sehingga memberi motivasi dan dorongan, untuk secara terbuka masing-masing mahasiswa ke arah tujuan yang sama.

\section{C.SIMPULAN}

Metode vasTmind dapat memecahkan permasalahan dari adanya keterlambatan pengerjaan projek, diantaranya: 1.) Segala aktivitas penyelesaian proyek terdokumentasi secara rapih di dalam sebuah vasTmind penelitian. Sehingga, mahasiswa tidak perlu repot mencari data-data penelitian yang telah didokumentasikan. Karena setiap pekerjaan yang sudah dikerjakan, secara jelas disertakan dengan link pembuktian penyelesaian; 2.) Dengan dukungan jaringan internet, vasTmind diakses secara online, dan data yang tertampil merupakan data real-time proyek, sehingga memudahkan mahasiswa dalam proses penyelesaian proyek kapanpun dan dimanapun, dan juga tidak perlu menggunakan kertas dalam proses pengerjaan. Cukup dengan keahlian dalam menggunakan lembar kerja yang disediakan oleh google, segala pekerjaan dapat diselesaikan dengan efisien dan efektif; 3.) Proses bimbingan tidak harus bertatap muka, karena segala instrumen penelitian disediakan secara online.
Dengan adanya contributor pada vasTmind, dosen juga dapat melihat kualitas masing-masing mahasiswa dalam proses penyelesaian proyek.

Penggunaan metode vasTmind pada mahasiswa bimbingan sudah terbukti berhasil dan sangat efisien dan efektif. Hal ini dapat diimplementasikan juga dalam kegiatan belajar mengajar di kelas, agar dosen dan mahasiswa dapat saling berkolaborasi dalam proses pembelajaran.

Disarankan juga, sekiranya ilmu vasTmind ini juga dapat diimplementasikan oleh manajer pada perusahaan. Sehingga dapat dicari tahu, apakah metode vasTmind ini dapat bermanfaat juga untuk kalangan usaha atau bisnis.

Bagi peneliti yang akan meneliti penggunaan metode vasTmind sebagai collaborative learning, hendaknya menggunakan sampel yang lebih luas lagi, untuk dapat mengukur secara kuantitatif dan menguji secara menyeluruh persentase keberhasilan metode vasTmind ini dalam penyelesaian projek kerja lainnya.

\section{DAFTAR PUSTAKA}

Aini, Q., Alwiyah, A., \& Putri, D. M. (2019). Effectiveness of Installment Payment

Management Using Recurring Scheduling to Cashier Performance. Ap- 
tisi Transactions on Management (ATM), 3(1), 13-21.

Anwar, B., Munzil, M., \& Hidayat, A. (2019). PENGARUH COLLABORATIVE LEARNING DENGAN TEKNIK JUMPING TASK TERHADAP KETERAMPILAN BERPIKIR KRITIS DAN HASIL BELAJAR SISWA. Jurnal Pembelajaran Sains, 1(2).

Atmadja, A. T., \& Saputra, K. A. K. (2018). Pengaruh Budaya Universitas Terhadap Kinerja Mahasiswa Akuntansi Dengan Kreativitas Sebagai Variabel Moderasi (Studi Pada Mahasiswa Akuntansi di Perguruan

Tinggi Se-Kabupaten Buleleng). Jurnal Akuntansi Aktual, 5(1), 22-30.

Beel, J., Langer, S., Kapitsaki, G., Breitinger, C., \& Gipp, B. (2015, June). Exploring the potential of user modeling based on mind maps. In International Conference on User Modeling, Adaptation, and Personalization (pp. 3-17). Springer, Cham.

Davies, M. (2011). Concept mapping, mind mapping and argument mapping: what are the differences and do they matter?. Higher education, 62(3), 279-301.

Karunarathne, A., \& Weerasinghe, W. A. M. K. The application of mind mapping as a technique to enhance collaborative, creative, and innovative learning among Geography undergraduates.

Koznov, D., \& Pliskin, M. (2008, October). Computer-supported collaborative learning with mind-maps. In International Symposium On Leveraging Applications of Formal Methods, Verification and Validation (pp. 478-489). Springer, Berlin, Heidelberg.

Latifah, R., Latifah, R., Hidayat, A., \& Hidayat, A. (2017). Penerapan Model Pembelajaran Cooperatif Integrated Reading and Composition (CIRC) dengan Mind Mapping terhadap Kemampuan Berpikir Kritis Siswa Kelas XI IPA SMAN 1 Bojongsoang Pada Materi Sistem Ekskresi (Doctoral dissertation, UIN Sunan Gunung Djati Bandung).

Nur, M., Noviana, E., \& Syahrilfuddin, S. (2018). PENERAPAN MODEL PEMBELAJARAN KOOPERATIF TIPE MIND MAPPING UNTUK MENINGKATKAN HASIL BELAJAR PKn SISWA KELAS V SD NEGERI 59 SEBANGAR KECAMATAN MANDAU. Jurnal Online Mahasiswa (JOM) Bidang Keguruan dan Ilmu Pendidikan, 4(1), 1-14.

Puspita, H. (2018). Studi Strategi Melalui Pendekatan Pengukuran Kinerja Dengan Metode Balanced Scorecard. Jurnal Industri Elektro dan Penerbangan, $1(1)$.

DOI:https://doi.org/10.17509/e.v18i1.14919 
Rahardja, U., Moein, A., \& Lutfiani, N. Leadership, Competency, Working Motivation and Performance of High Private Education Lecturer with Institution Accreditation B: Area Kopertis IV Banten Province. Man India, 97(24), 179192.

Rahardja, U., Aini, Q. and Zuliana, S.R., 2016. Metode Learning Management System (LMS) iDu Untuk Mendukung Kegiatan Belajar Mengajar MIT Pada Perguruan Tinggi Raharja. CICES Journal, 2(2), pp.156-172.

Rahardja, U., \& Roihan, A. (2017). Design of Business Intelligence in Learning Systems Using iLearning Media. Universal Journal of Management, 5(5), 227-235.

Rahardja, U., Aini, Q., Ariessanti, H. D., \& Khoirunisa, A. (2018). Pengaruh Gamifikasi pada iDu (iLearning Education) dalam Meningkatkan Motivasi Belajar Mahasiswa. Nusantara Journal of Computers and its Applications, 3(2).

Rahardja, U., Aini, Q., \& Putri, D. M. (2018). Pemanfaatan Automated Email System (AEMS) Sebagai Media Notifikasi Penilaian Hasil Belajar. SENSITEK, 1(1), 49-54.

Shapiro, H. B., Lee, C. H., Roth, N. E. W., Li, K., Çetinkaya-Rundel, M., \& Canelas, D. A. (2017). Understanding the massive open online course (MOOC) student experience: An examination of attitudes, motivations, and barriers. Computers \& Education, 110, 35-50.

Spector, J. M., \& Park, S. W. (2017). Motivation, Learning, and Technology: Embodied Educational Motivation. Routledge. 